Cahiers $d u$ MONDE RUSSE

\section{Cahiers du monde russe}

Russie - Empire russe - Union soviétique et États indépendants

$41 / 2-3 \mid 2000$

En islam sibérien

\title{
Ethnic processes within the Turkic population of the West Siberian plain (sixteenth-twentieth centuries)
}

\section{Nikolaj A. Tomilov}

\section{(2) OpenEdition \\ 1 Journals}

\section{Electronic version}

URL: https://journals. openedition.org/monderusse/44

DOI: 10.4000/monderusse.44

ISSN: $1777-5388$

\section{Publisher}

Éditions de l'EHESS

\section{Printed version}

Date of publication: 1 April 2000

Number of pages: 221-232

ISBN: 2-7132-1361-4

ISSN: $1252-6576$

\section{Electronic reference}

Nikolaj A. Tomilov, "Ethnic processes within the Turkic population of the West Siberian plain (sixteenth-twentieth centuries)", Cahiers du monde russe [Online], 41/2-3 | 2000, Online since 15 January 2007, connection on 06 September 2022. URL: http://journals.openedition.org/monderusse/ 44 ; DOI: https://doi.org/10.4000/monderusse.44 


\title{
ETHNIC PROCESSES WITHIN THE TURKIC POPULATION OF THE WEST SIBERIAN PLAIN
}

\author{
(sixteenth-twentieth centuries)
}

THE BASIC AIM OF MY SCHOLARSHIP over many years has above all been the study and solution of problems in the ethnic history of the Turkic population of the West Siberian plain, beginning with Siberia's incorporation into the Russian state in the second half of the sixteenth century, right down to the beginning of the twentieth century. The broadness of the period under consideration is connected to the fact that the characterization of the ethnic development of this region's Turkic groups on the basis of more narrow time frames has led to a series of erroneous and exaggerated statements in the fields of ethnography and history. For example, such statements have been made concerning the significant layers of Volga Tatars within the composition of the native Siberian Tatars and concerning their powerful influence in Siberia in the eighteenth and nineteenth centuries, concerning the lack of common ethnic elements within the Turkic groups of the native population, the lack of ties between them, concerning the reduction or lack of population growth for the Turkic population in different periods, and so forth.

The following specific tasks were established to carry out this aim:

1) to study the ethnic make-up of the Turkic population and to isolate the ethnic and ethnographic groups,

2) to study, as far as possible, issues of the origins of the native Turkic population and the formation of its separate groups,

3) to follow the changes in their locations and numbers, and to determine the level of viability of a given group, and their ethnic reproduction,

4) to study the ethnic processes within the various groups of the Turkic population (to examine the system of social and economic ties, ethnocultural and ethnolinguistic processes, and the formation of ethnic consciousness), 
5) to reveal the role of inter-ethnic ties of the Turkic groups, among themselves, with the native peoples of Siberia, and with the Russians in a given region, and the role of these ties in the development of ethnic processes,

6) to study the changes in the ethnic situation of the Turkic population, to determine the taxonomy of ethnic formations among the Siberian Tatars, Kazakhs, Chulym Turks, and Siberian Bukharans, among others, together with the fundamental tendencies of their ethnic development.

The main sources for carrying out these tasks have been written materials located in a series of archives and collections. These include the Russian State Archive of Ancient Documents (Rossiiskii Gosudarstvennyi Arkhiv Drevnikh Aktov - RGADA) in Moscow, the Russian State Historical Archive (Rossiiskii Gosudarstvennyi Istoricheskii Arkhiv - RGIA) in St. Petersburg, the state archives of Omsk and Tomsk oblasti, and the Tobol'sk branch of the State Archive of Tiumen' oblast'. The basic sorts of materials that were used were iasachnye knigi (Iasak lists), imennye knigi sluzhilykh liudei (servitor lists), krestoprivodnye knigi (juror lists), okladnye knigi podatnogo naseleniia (tax registers), lists of settlements for districts (okrugi) and volosti, materials of the First, and the Third through the Tenth Censuses (revizii) kept in union registers, and, what are especially valuable, the initial copies of the lists in local archives, petitions, and petition correspondence, servitor correspondence, reports, and complaints. We extracted other data from the archive of the Museum of Anthropology and Ethnography (St. Petersburg), from the archival department of the Russian State Ethnographic Museum (St. Petersburg), as well as from manuscripts in the archive of the Tobol'sk State Historic Architecture Museum-Park.

I also made use of published documents from the multi-volume publications Akty istoricheskie, Dopolneniia $k$ aktam istoricheskim, Russkaia istoricheskaia biblioteka, as well as those in the works of I. P. Kuznetsov-Krasnoiarskii, G. N. Potanin, and in those of others. Considerable important information is contained in the works of scholars, travelers, and exiles from the sixteenth to the beginning of the nineteenth centuries. Data of this sort, collected in the special works of M. P. Alekseev, E. P. Zinner, Z. D. Titova, as well as in the works of eighteenth-century scholar-travelers such as I. G. Georgi, S. P. Krasheninnikov, P. S. Pallas, P. von Strahlenberg, and others were used in these studies. Much information was also acquired from studies published in the nineteenth and twentieth centuries.

Materials collected by the historical and ethnographic expeditions of Omsk and Tomsk Universities were also included in the work. These expeditions took place under the direction of this article's author from 1969 to 1985, and were conducted among various groups of Tobol'sk, Irtysh, Baraba, and Tomsk Tatars, Teleuts, Chulym Turks, Kazakhs, Volga Tatars, and other Turkic groups and peoples of Western Siberia. The field materials include data on ethnonyms, the names of tugums (groups of related families), genealogies, materials on economic, material, and spiritual life, historical folklore, traditions concerning historical events, and in some cases questionnaires for the study of current ethnic processes, etc. A portion of the materials included in the work was collected by participants in the fieldwork 
of Tomsk University in 1964, and 1970-1974, and of Omsk University from 1975 to 1985 . In the study of ethnogenetic and ethno-historic processes, physical anthropological materials were partially used, specifically dermatoglyphic series collected in 1976-1978 among all groups of the Turkic population of the West Siberian plain by Omsk University's Siberian historical and ethnographic expedition, and processed by G. L. Khit' in the Institute of Ethnography of the Academy of Sciences of the USSR.

In the study of ethnocultural processes materials were used from the State Museum of the Ethnography of the Peoples of the USSR, the Peter the Great Museum of Anthropology and Ethnography, the Omsk University Museum of Archeology and Ethnography, Tomsk University's Museum of the Archeology and Ethnography of Siberia, the Omsk State Museum of History and Literature, the Tobol'sk State Historic Architecture Museum-Park, as well as the Local History Museums of Novosibirsk, Tomsk, and Tiumen' oblasti.

I can mention the successful investigations of a series of scholars from the eighteenth and nineteenth centuries in approaching issues of ethnogenesis and ethnic make-up (the works of N. A. Aristov, V. V. Radlov, I. Iushkov, and N. M. Iadrintsev), such as ethnic processes, the merging of local groups of Siberian Tatars with Bukharans or with immigrant Tatars from the Volga-Ural region, and the bringing together of the Turkic and Russian populations (the works of I. G. Georgi, P. S. Pallas, S. K. Patkanov, N. M. Iadrintsev, and others). But regardless of their valuable observations and conclusions, limitations regarding specific issues is also evident in these authors. In some works, they identify Turkic groups not belonging to this ethnic community as Siberian Tatars. The level of the Siberian Tatars' linguistic and cultural proximity with Volga-Ural Tatars was overstated, and the ethnic uniqueness of the Siberian Tatars' culture and way of life was denied. The theory of the Russification of Siberian Tatars and Chulym Turks does not hold up to criticism.

Definite scholarly achievements in studying various historical issues emerged in the twentieth century (the works of S. V. Bakhrushin, Z. Ia. Boiarshinova, B. O. Dolgikh, N. F. Emel'ianov, V. I. Ogorodnikov, A. P. Okladnikov, V. S. Siniaev, A. P. Usmanskii, and others), as well as in physical anthropology (the works of A. N. Bagashev, G. F. Debets, V. A. Dremov, A. R. Kim, N. S. Rozov, T. A. Trofimova, G. L. Khit', and others), in archeology (the works of Z. Ia. Boiarshinova, V. D. Viktorova, A. P. Dul'zon, B. A. Konikov, V. P. Levasheva, V. I. Matiushchenko, V. A. Mogil'nikov, V. I. Molodin, A. F. Palashenkov, L. M. Pletneva, D. G. Savinov, I. D. Smirnov, V. I. Sobolev, S. S. Tikhonov, T. N. Troitskaia, and others) in linguistics (the works of M. A. Abdrakhmanov, G. Kh. Akhatov, O. I. Gordeeva, L. V. Dmitrieva, A. P. Dul'zon, S. M. Iskhakova, D. G. Tumasheva, and others), all of whom addressed issues relating to the Turkic population of the West Siberian plain. The appearance of a whole series of works on the ethnography of the Siberian Tatars has characterized the ethnographic literature of the Soviet and post-Soviet periods. This includes the works of I. I. Avdeev, I. P. Strukova, F. V. Akhmetova, V. G. Bogomolov, V. T. Valeev, R. I. Eremin, P. G. Ivanov, S. V. Ivanov, S. N. Korusenko, N. V. Kuleshova, Sh. Kh. Monasypov, S. Iu. Pervykh, R. K. Satlikova, 
A. G. Seleznev, N. A. Tomilov, V. V. Khramova, and others. A. P. Dul'zon, P. G. Ivanov, E. L. L'vova, L. P. Potapov, and others have addressed the Chulym Turks, Sh. K. Akhmetova, I. V. Zakharova, A. V. Konovalov, O. V. Naumova, O. M. Provatorova, and others have dealt with the Kazakhs of Western Siberia, and N. V. Bikbulatov, R. G. Kuzeev, M. V. Murzabulatov, S. N. Shitova, and others with the Trans-Ural Bashkirs. The great contributions of F. T. Valeev in the study of the origins and ethnic history of the Siberian Tatars, and of E. L. L'vova in the study of the ethnogenesis of the Chulym Turks deserve special mention.

I should note that a single approach to the classification of the population under investigation, with respect to their linguistic and ethnographic features, has still not been worked out. This has revealed a certain vagueness and lack of development in some issues linked to ethnic processes among the Siberian Tatars, including the issue of the degree of their being consolidated within the larger Tatar community in Russia as a whole. It is evident that the tendency of some current scholars to overestimate the similarity of the culture of the Siberian and Volga Tatars, and the denial of the Siberian Tatars' traits that distinguish them from the surrounding Russian population originates from nineteenth-century literature. To a significant degree, this tendency stems from the fact that until quite recently, the ethnography of the Siberian Tatars remained insufficiently studied. Indeed, issues concerning the development of ethno-cultural processes among the Chulym Turks, Kazakhs, and immigrant Volga-Ural Tatars and their descendants were quite neglected.

In my works, ${ }^{1}$ the main focus of attention has been to divide into separate groups the Siberian Tatars, Chulym Turks, Siberian Bukharans and other descendants of Central Asians, Volga Tatars, and Kazakhs, who, in the period under consideration made up a significant portion of the population. In addition, in this region, during various periods from the sixteenth to the beginning of the twentieth centuries, there were Bashkirs, Yenisei Kyrgyz, Noghays, Teleuts, Chuvash, and among the nonTurkic peoples there were Jungars, Kalmyks, Mansi, Selkups, Khanty, and others.

I worked out an ethnographic classificatory system, that was in many respects new, for the ethnography of the Turkic population of the West Siberian plain in the period under consideration. Among the so-called Siberian Tatars I have isolated the following ethnographic groups and identified the component ethno-cultural subgroups within them as well:

1) Tiumen'-Tura Tatars and their sub-groups: 1) Tiumen', 2) Ialutor, 3) Tura, 4) Upper Tura,

1. Ocherki etnografii tiurkskogo naseleniia Tomskogo Priob'ia (ethnicheskaia istoriia, byt $i$ dukhovnaia kul'tura) (Tomsk: Izdatel'stvo Tomskogo Universiteta, 1983); Problemy rekonstruktsii etnicheskoi istorii naseleniia iuga Zapadnoi Sibiri (Omsk: Izdanie Omskogo Universiteta, 1987); Problemy etnicheskoi istorii (Po materialam Zapadnoi Sibiri) (Tomsk: Izdatel'stvo Tomskogo Universiteta, 1978); Tiurkoiazychnoe naselenie Zapadno-Sibirskoi ravniny $v$ kontse XVI-pervoi chetverti XIX VV. (Tomsk: Izdatel'stvo Tomskogo Universiteta, 1981); Etnicheskaia istoriia tiurkoiazychnogo naseleniia Zapadno-Sibirskoi ravniny $v$ kontse $X V I$-nachale $X X \quad$ v. (Novosibirsk: Izdatel'stvo Novosibirskogo Universiteta, 1992); Etnografiia tiurkoiazychnogo naseleniia Tomskogo Priob'ia (Khoziaistvo i material'naia kul'tura) (Tomsk: Izdatel'stvo Tomskogo Universiteta, 1980); F. T Valeev and N. A. Tomilov, Tatary Zapadnoi Sibiri: istoriia i kul'tura (Novosibirsk: Nauka, 1996). 
2) Tobol'sk Tatars and their sub-groups: 1) Aremzian-Nadtsi, 2) Isker-Tobol'sk, 3) Babasan, 4) Ishtiak-Tokuz,

3) Iaskolba Tatars and their sub-groups: 1) Iaskolba, 2) Koshuk, 3) Tabara,

4) Kurdak-Sargat Tatars and their sub-groups: 1) Kurdak, 2) Sargat-Utuz,

5) Tara Tatars and their sub-groups: 1) Aialy, 2) Turali,

6) Barabas and their sub-groups: 1) Baraba-Turazh, 2) Liubei-Tunus, 3) TerenaChoi,

7) Tomsk (Eushta) Tatars and their sub-groups: 1) Eushta, 2) Basandai, 3) Evaga,

8) Chats and their sub-groups: 1) Ob', 2) Tom',

9) Ob' Tatars and their sub-groups: 1) Temerchi, 2) Shegar, 3) Prov-Sorgula, 4) Chernomys,

10) Kalmaks.

The Chulym Turks are divided between the Lower Chulym and Middle Chulym (Meles) Turks. The former division is made up of the Baigul-Karagach, Argun, Kyzyldei, Iach, Kuriuk, and Kurchik groups. The Kazakhs in the southern regions of the West Siberian plain constitute the West Siberian ethnographic group of the Kazakh people. Four groups are distinguishable among the Siberian Bukharans: 1) Tiumen', 2) Tobol'sk, 3) Tara, 4) Tomsk. Groups of Volga-Ural Tatars also formed in Western Siberia, in regions isolated from the Siberian Tatars: 1) Mariinsk, 2) Zyrian-Krivoshei, 3) Kolpash-Chaia, 4) Soroka.

In my opinion, local tribes, whose ancestors were the earliest Turkic settlers in the region formed the foundation of the Tiumen'-Tura Tatars. Groups of Bashkir origin, or more exactly, groups that were merged into both the Tiumen'-Tura Tatars, and the Bashkirs, are also evident among the Tiumen'-Tura Tatars. Together with these, groups from early Uzbek tribes, recognized as descendants of Central Asian khoja groups, also merged with the Tiumen'-Tura Tatars, and constitute another element of ethnic particularity. In the sixteenth to the beginning of the twentieth centuries they actively intermixed with the Bukharans (primarily Uzbeks and Tajiks), and partially with the Tobol'sk and Iaskolba Tatars. In this historical period the Ialutor Tatars became sharply distinguished. Tiumen' Tatars formed the basis of this group, but there was also a Tobol'sk Tatar component. Similarly, the Tura Tatars were primarily Tiumen' Tatars, but local Mansi ancestors also formed a significant element in this group. The attempt to determine the ethnic make-up of the Tura Tatars as being singularly Mansi should be seen as untenable. Tiumen'-Tura Tatars mixed with Volga Tatars and Bashkirs formed the ethnic foundation of the Upper Tura Tatars.

The fundamental ethnic component for all of the Tobol'sk Tatar groups in that period are the ancestors of the oldest population of these regions, the Turks of the "Taybugha clan." Another common element were the Ugrians. The AremzianNadtsi sub-group was characterized by their assimilation of small groups of Irtysh Khanty, and possibly Mansi, and by the absence of intermixture with Bukharans or Volga Tatars, as well as possible ties with the Teleuts. In the period under consideration, Isker-Tobol'sk, Babasan, and Iaskolba Tatars intermixed with the Aremzian-Nadtsi Tatars. In addition to the general Tobol'sk elements, the Isker- 
Tobol'sk Tatars were mixed with Central Asian Turks (mainly Uzbeks, and to a lesser degree, Kazakhs), Kazan Tatars, and Chuvash. A unique feature of the Babasan group is the strong stratum of Tatars of the "Taybugha clan," in conjunction with Isker-Tobol'sk Tatars, as well as the lack of Bukharans and Kazan Tatars in their composition. Among the Ishtiak-Tokuz group, the layer of southern Ugrians is more prominent, as well as their intermixing with the Isker-Tobol'sk and Kurdak-Sargat Tatars in the period under consideration. In the eighteenth century so-called obrochnye chuvalshchiki settled among the Tobol'sk Tatars. These individuals were a mixed Kazan Tatar and Siberian Tatar group.

Within the small group of Iaskolba Tatars, Old Turkic, Qïpchaq, Ugrian, and Samoyed elements are sharply evident, and the absence of Bukharans and Kazan Tatars are noted. The intermixing of the Iaskolba Tatars with Tiumen' Tatars and Mansi was, it seems to me, a particularity of the formation of the small peripheral group of the Koshuk Tatars. Iaskolba and Tura Tatars, as well as Mansi, made up the foundation of the Tabara Tatars.

The general ethnic components of the Kurdak-Sargat Tatars during this period were the descendants of the earliest Turkic settlers in the area, southern Khanty, as well as Noghay and Tobol'sk Tatar elements (the latter date from the 1580's). The lack of intermixing with Bukharans was a characteristic feature. It is true that Sarts did enter into the composition of the Kurdak-Sargat Tatars, but these were, apparently, earlier Uzbeks. In addition, the Qïpchaq layer among the Kurdaks is evinced by the ethnonym Qaraqïpchaq. The particularity of the Sargat-Utuz Tatars is the inclusion into their make-up of the descendants of the Khitans, an originally Mongol group that later became Turkicized, and of the descendants of the "Otuz Tatars" of the Orkhon Inscriptions. Immigrant Volga-Ural Tatars settled among the Kurdak-Sargat Tatars somewhat later, mainly in the late nineteenth and early twentieth centuries.

The common character of the Tara Tatars is evident, not only by the fact that the Aialy formed a separate group, but were included in the make-up of the Turali. Both groups of Tara Tatars shared common Teleut, Baraba, and older Ugrian components. From the seventeenth century until the middle of the nineteenth century Kazan Tatars were only encountered here individually, and at that time did not affect the ethnic make-up of the local Tatars. The peculiarity of the Tara Tatars was that they were the descendants of Pecheneg-Oghuz and Oghuz-Qïpchaq tribes. Also, from the end of the eighteenth century Bukharans and a few Karakalpaks entered into the make-up of the Turali.

There were many descendants of early Turkic tribes from the Altai Mountains among the Barabas. The Altai stratum was reinforced by the inclusion of Teleuts in their make-up. All the Baraba groups shared a Tara Tatar (mainly Aialy) component. Within the most numerous group, the Baraba-Turazh group, there were also Sarts from Central Asia (Uzbeks and Tajiks) of a relatively early origin, as well as Kazakhs, Bashkirs, Orchaks (Turkic relatives of the Tuvins from the Sayan-Altai plateau), Ugrians, Samoyeds, and Western Mongols (Kalmyks). The latter are also evident within the Terena-Choi group. Ugrian and Central Asian components 
(Tajiks and Uzbeks) are evident in the Liubei-Tunus group. During their contacts with the Kuchumids, it is possible that some Tobol'sk Tatars were included in their make-up.

Southern Samoyeds, Old Turks, including Kyrgyz and Teles tribes, Kimäks, and then from among them, Qïpchaqs, all left their trace in the make-up of the Tomsk (Eushta) Tatars. From the end of the sixteenth century up to the nineteenth century Tobol'sk-Irtysh Tatars, and partially Bukharans (Uzbeks) and Chulym Turks entered into their composition.

The common ethnic components of the Chats include Tobol'sk-Irtysh Tatars, Barabas, Kazakhs, Teleuts, and local Turks descended from early native Turks of the Ob' Valley. In my opinion, the roots of the Chats go back mainly to the Kimäks' Shad tribe. The particularities of the Tom' Chats, who became distinct in the seventeenth century, was their mixing with Eushtas, Bukharans, and in part with Western Mongols (Kalmyks). Old settlers along the Middle Ob' River (descendants of Turkicized, or partially Turkicized southern Samoyeds), were descendants of Khitays, as well as Selkups, to different degrees in different areas. Descendants of Teleuts could be found among all groups, with the exception of the Prov-Sorgula Tatars. Chats, and some Eushta Tatars, and Chulym Turks entered into the composition of the Shegars. The Temerchis included in their composition a few Eushta Tatars, Chats, and possibly Barabas. Among the Prov-Sorgula Tatars there were Eushta and Tobol'sk-Irtysh Tatars, and in the eighteenth century, some Chulym Turks. Chulym Turks and Temerchis, mixed with some Chats and Teleuts, formed the Chernomys Tatars. The Kalmaks, who are usually considered to be the descendants of Teleuts, were formed not only from them. They also included native Turks from the lower (northern) coastal regions, Mongol elements mixed with Chats and Eushtas.

In the process of the formation of the Chulym Turks from the end of the seventeenth century to the eighteenth century, in part Selkups, Kets, Yenisei Kyrgyz, Kyzyl Turks, as well as a small number of Siberian Tatars from the western groups, and Eushta Tatars and Teleuts, all merged into their ethnic composition. The Kazakhs in Western Siberia were primarily made up of Qïpchaqs, Arghïns, Naymans, Kereys, Waqs, Zhetiru, and others. The vast majority of Siberian Bukharans were of Uzbek or Tajik origin, but in addition, among them there were Uyghurs, Kazakhs, Turkmens, and, evidently, Karakalpaks, and in Siberia they mixed to some degree with Siberian and Kazan Tatars. In addition, Karakalpaks were present in Western Siberia in small numbers in the Tobol-Irtysh region. The immigrant Volga-Ural Tatars were Kazan Tatars, Mishars, and Kriashens. In my works I present facts on the specific places of origin of the Turkic population from Central Asia, and the Volga-Ural region, and the issue of the chronology of their migrations are examined.

With the coming of the Russian to Western Siberia, a portion of the Tobol'skIrtysh Tatars migrated to the Ob' region and further east. The Tiumen'-Tura Tatars settled in the seventeenth and eighteenth centuries lower down the Tura and Tavda Rivers, to the Tobol, and somewhat to the south, where the formation of the Ialutor 
Tatars took place. The Tobol'sk Tatars partially migrated to the "Trans-Marsh" (Zabolotnyi) region, inhabited by the Iaskolba Tatars, to the north, into the lands of the Khanty and Mansi, and up the Irtysh, to the Kurdak-Sargat Tatars. The Ialskolba Tatars migrated to the territory of the Tiumen' Tatars, while the KurdakSargat Tatars went up the Irtysh as far as the Baraba Wooded-Steppe. In their turn, the Barabas migrated westward, toward the Tara Tatars, and partially toward the east, where they mixed with the Chats, and possibly with the Chulym Turks and the Khakas. Along the Ob' and Tom' Rivers, the Eushta Tatars settled widely in the Ob' Valley, on the lands of the Kalmaks, Chats, and Ob' Tatars, and also on the Chulym River. The Chats settled on Eushta territory, including along the Tom', and the Ob' Tatars went toward the north. In the seventeenth and eighteenh centuries the territory of the Kalmaks became stable, and they settled in proximity to the Chats and Eushtas.

In the period under consideration we have noted the phenomenon of the disappearance and appearance of various settlements, the consolidation of settlements, the migrations of the Turkic population to Russian cities, the joint residence of Siberian Tatars with members of other nationalities (Siberian Bukharans, Volga Tatars, Bashkirs, Kazakhs, Karakalpaks, Teleuts, Chulym Turks, Selkups, Mansi, Khanty, as well as with Russians).

The Chulym Turks migrated into a number of different areas. Some Meleses went into the Kyzyl Tatars' areas, Chulym Turks made northern migrations into the lands of the Selkups and Kets, others moved into the territories of the Ob' Tatars, Chats, and Eushta Tatars, small groups migrated in an eastern or southeastern direction, and other groups settled in Russian villages along the Chulym, Tom', and Ob' Rivers. Kazakhs gradually settled in the southern areas of Western Siberia from the end of the sixteenth century down to the eighteenth. Changes in the nineteenth and twentieth centuries consisted of Kazakhs moving into Volga Tatar settlements in Ishim district (okrug), and in Siberian Tatar and Russian settlements in Tiumen' district. The Siberian Bukharans were settled in four compact groups among the Tiumen', Tobol'sk, Tara, and Tomsk Tatars, as well as in the cities of Western Siberia. The Volga Tatars settled in the villages of various Siberian Tatar groups, with the exception of the Iaskolba settlements, but they also formed their own communities in Ishim, Kurgan, Tiukali, and Surgut districts of Tobol'sk province.

The materials show that during the period under discussion, the numbers of most of these Siberian Turkic groups increased. For the seventeenth century we have detailed data on the Service Tatars, there is information on the Zakhrebetnye and baptized Tatars, supplying a corrective for the figures with relation to the new coefficients, and in turn this gives us more exact figures. Thus, at the end of the sixteenth century the total number of Tobol-Irtysh Tatars was 10,000, at the end of the seventeenth century it was 14,400, in the middle of the eighteenth century it was around 17,500, in 1816 almost 24,500, and in 1897, 37,600. At the end of the sixteenth century the Barabas numbered approximately 1,500 to 2,000 . In the seventeenth century no growth was observed among them, in the middle of the eighteenth century they numbered about 1,900. During the second half of the 
eighteenth, to the beginning of the nineteenth century, their number continued to grow, reaching nearly 5,000 in 1823. Later in the nineteenth century their numbers did not increase, and even declined, to 4,400 in 1897 . At the beginning of the seventeenth century the Eushtas numbered around 800 people, then in the seventeenth and eighteenth centuries their number sharply declined (down to 170 people in 1824). However from the 1830's their number increased to 290 rural inhabitants by 1897 . Over the course of the seventeenth century the number of Chats remained constant (around 400), and in the eighteenth century it grew by $50 \%$, and by the end of the nineteenth century they numbered about 1,000 people. The first complete data on the Kalmaks are found in the data for 1805, when they were said to number 429 people, and in 1897 this number had risen to 688. The overall number of Tomsk Tatars at the end of the nineteenth century was nearly 2,200. In addition, along the Ob', in the Tomsk region, there were about 3,000 Ob' Tatars. As a whole, all the Siberian Tatar groups numbered 16,500 people at the end of the seventeenth century, 28,500 at the end of the eighteenth century, and more than 47,000 at the end of the nineteenth century.

In the seventeenth century the number of Chulym Turks fell by about $20 \%$, to 830 people, at the beginning of the nineteenth century (1816) they numbered 3,900, and at the end of the nineteenth century, 4,825. In 1816 there were 869 Kazakhs in Tobol'sk province, but by 1823 , they numbered 1,622 in Omsk district alone. In 1897 , on the West Siberian plain as a whole, there were over 50,000 Kazakhs. At the end of the sixteenth and the beginning of the seventeenth centuries the number of Siberian Bukharans was 1,200, and at the end of the nineteenth century they were 11,500. Before the 1860's the number of Volga-Ural Tatar settlers in Siberia grew slowly, and in 1858 they numbered only about 700 for the entire West Siberian plain. By 1897 their number had grown to 14,400. 565 Bashkirs lived in the districts of Tobol'sk and Tomsk provinces.

In the course of investigating the issues of ethnic processes among the Siberian Tatars, the following outline of the mutual interconnection of a number of Turkic groups emerged, with respect to the degree of joint neighboring settlement, to certain aspects of mutual association, as well as to the presence of common ethnic components constituting the make-up of a given group in the period under consideration (especially with respect to the migration of Tobol-Irtysh Tatars and Barabas to the east).

The Tobol'sk Tatars had the most numerous ties, that connected them with all of the other territorial and ethnic groups, with the exception of the Kalmaks. Naturally, these ties became weaker with the Barabas, Eushta Tatars, Chats, and Ob' Tatars who were settled further to the east. At that time the Tiumen' Tatars were closely connected with the Tobol'sk and Iaskolba Tatars, and less so with the Kurdak-Sargat and Tara Tatars. A gradually defined rift developed between the Tiumen' Tatars, on the one hand, and the Tura and Upper Tura Tatars on the other, in a formerly unified territory, and these connections weakened. The Tara Tatars also maintained ties in a number of directions, with the Kurdak-Sargat, Tobol'sk, Tiumen', and Tomsk Tatars, and with the Barabas. 
In the east, the hub of ethnic and historical connection was primarily centered among the Chats and Eushta Tatars. The Chats had ancient kinship ties with the Tobol-Irtysh Tatars, and in the seventeenth to the beginning of the twentieth centuries they were mainly in contact with the Barabas, Tomsk Tatars, and Kalmaks, and to a lesser degree with the Tobol'sk Tatars. A territorial gap arose between the Chats and the Barabas, but nonetheless they did retain direct ties for a long time, especially between the Ob' Chats and the Barabas. In the lower reaches of the Tom', and the adjoining areas along the Ob', the Chats were a more numerous group compared with the Eushtas and Kalmaks. This circumstance meant that upon intermixing with the local groups, they imparted large groups into the local Turkic population and infused traits of the Tobol-Irtysh Siberian Tatar ethnocultural complex into their culture and language. At that time the Eushtas not only maintained contacts with the neighboring Chats, Kalmaks, and Ob' Tatars, but also with the Barabas, Tobol'sk, and Tara Tatars. Ethnogenetic ties even bound this, the most easterly of groups in question, with the Iaskolba Tatars, the most westerly ethno-territorial group of Tobol-Irtysh Tatars.

The Barabas, who occupied an intermediate position between the Tobol-Irtysh groups on the one hand, and the Tom'-Ob' groups on the other, primarily maintained ties with the Tara Tatars and Chats, as well as with the Eushtas. The narrowest range of contacts were among the Iaskolba Tatars (with the Tiumen' and Tobol'sk Tatars) and among the Kalmaks (with the Chats, Eushtas, and Ob' Tatars). This is understandable, if we keep in mind the geographically peripheral location of these groups.

As a whole, these contacts demonstrate, in my opinion, a rather high degree of interconnectedness among the Tobol-Irtysh, Baraba, and Tom'-Ob' Turkic groups, which allowed the development of the groups' mutual consolidation.

Studying the processes of the Siberian Tatars' ethnic development, who made up the majority of the Turkic population here, and examining specifically the level of socioeconomic development, their social and economic networks, their ethnocultural and ethnolinguistic processes, and the changes in their ethnic consciousness over the course of the sixteenth to the beginning of the twentieth century, allows us to investigate issues of the formation of ethno-territorial groups. Thus, among the Siberian Tatars processes of ethnogenetic consolidation led to this formation. The Tatar groups of the Tobol-Irtysh and Baraba regions existed already at the end of the sixteenth and in the seventeenth centuries; later ethnic processes amongst them bore an ethno-evolutionary character. In the nineteenth century the Tomsk Tatar groups constituted an ethnically united whole, but finally coalesced in the first decade of the twentieth century.

Throughout the period under consideration the Siberian Tatars were developing into a single ethnic community, and already in the seventeenth and eighteenth centuries they identified themselves as a historical and ethnic community. A peculiarity of the ethnic processes taking place among them was that given the absence of conditions for transforming the Siberian Tatars into an ethno-social organism, chief of which was their scattered settlement, what took place was their 
consolidation into an ethnos qua ethnikos. This process did not come to fruition, but it did lead to the fact that from the late eighteenth to the early twentieth centuries the Siberian Tatars conceived of themselves as a meta-ethnic (interethnic) community, close to an ethnos. As a result of their ethnic interactions with the Volga-Ural Tatars at the end of the nineteenth and the beginning of the twentieth centuries, a general meta-ethnic community came into being comprising the Tatars of the Volga-Ural region and Siberia, but a unified Tatar nation was not formed at that time. The Siberian Tatars' ethnic contacts with their neighbors resulted in partial assimilation with Russians, the assimilation of the part of the Tura Tatars with the Mansi, the merging of some Eushtas with the Chulym Turks, and the assimilation of part of the Tobol'sk Tatars with the Irtysh Khanty. By the same token, we can see that some Siberian Bukharans, Volga-Ural Tatars, Bashkirs, Karakalpaks, Khanty, Mansi, Selkups, Teleuts, Chulym Turks, and others assimilated with the Siberian Tatars.

At the time of the Chulyms' consolidation into the Chulym-Turk people, which primarily took place in the nineteenth century, a small part became assimilated by the Russians, and some Chulyms merged with the Kyzyl, Ob', and Tomsk Tatars.

Because of internal ethnic relations, and the relations with the Siberian Tatars, among Siberians of Central Asian origins, the Iranian-speaking Tajiks became Turkic-speaking, and new ethnic groups formed in Siberia, called the Siberian Bukharans, who gradually merged with the Siberian Tatars, and who at the end of the nineteenth and the beginning of the twentieth centuries, became part of the meta-ethnic community, which absorbed them, of the Tatars of the Siberia and the Volga-Ural region. A portion of the Kazakhs in Western Siberia merged with the Tobol-Irtysh Tatars and Barabas, but the vast majority of them, constituting the West Siberian ethnographic group of the Kazakh nation, were drawn in by the processes of inter-ethnic integration with the Russians and Tatars of Siberia. As for the Volga-Ural Tatar migrants and their descendants, their mass migration, which unfolded from the second half of the nineteenth to the beginning of the twentieth centuries, led to the creation of several groups and to their ethnic interaction with the local Siberian Tatars, which resulted in their partial merging with the latter, and also facilitated the formation of a unified inter ethnic community within a significant portion of the Tatar ethnic formations in Russia at that time.

Among the Turkic population of the West Siberian plain, the formation of a Muslim ethno-confessional community took place in the period under consideration. At the same time, a smaller proportion of Tatars, as well as Chulym Turks and Chuvash settlers, joined the Russians' ethno-confessional community. Here an ethno-linguistic community of the Turkic population was also formed, one which was relatively broader than the Muslim confessional community. With respect to the issue of the formation of traditional-cultural communities, the problem of distinguishing the West Siberian and South Siberian areal ethnohistorical communities has been resolved, placing the Sayan-Altai and South Siberian regional ethno-historical communities within the South Siberian areal community. The South Siberian regional ethno-historical community comprised the northern Kazakhs, various Siberian Tatar groups, Chulym Turks, Siberian 
Bukharans, Volga-Ural Tatars, Bashkirs, and in the historical past, a portion of the Noghays, Western Mongols, and others.

In Western Siberia, from the sixteenth century, the processes of the Turkic populations drawing together with the Russians developed and gained strength. The gradual growth of the progressive influence of the economic and cultural activities of Russians on the daily lives of local Turkic groups, the spread of bilingualism among the latter, the strengthening of trust between peoples and of the friendly ties of the local peoples with Russians allow us to conclude that together with the assimilation of part of the Turkic population by the Russians, inter-ethnic integrational processes developed most intensely, in which Russians played a dominant role concerning the economic and cultural transformation of the Turkic groups, and their rapid social and economic development.

(Translated from the Russian by Allen J. Frank)

Sibirskoe otdelenie Rossiiskoi Akademii Nauk

Omskii filial ob"edinennogo instituta istorii, filosofii i filologii

pr. Mira, 55a

644077 Omsk 